\title{
Evaluation of Cytotoxicity of A Nanoparticle Incorporated Root Canal Sealer - An In-Vitro Study
}

\author{
Srujana Hemmanur ${ }^{1}$ and Iffat Nasim ${ }^{2}$ \\ ${ }^{1}$ Saveetha Dental College and Hospitals, Saveetha Institute of Medical \\ and technical Sciences, Saveetha University, Chennai, India \\ ${ }^{2}$ Professor and Head, Dept of Conservative dentistry and Endodontics Saveetha Dental College and \\ Hospitals, Saveetha Institute of Medical and technical Sciences, Saveetha University, Chennai, India
}

\begin{abstract}
The objective of a root canal therapy is to remove the infected pulpal tissue and fill the enlarged canal spaces in such a way that a 3-D hermetic seal is obtained. For the obturation of the root canal space, an obturating core and a sealer are used. The sealer must be as biocompatible as possible with low cytotoxicity and genotoxicity and additional antibacterial properties. The aim of the current study was to evaluate the cytotoxicity of a silver nanoparticle incorporated root canal sealer using MTT Assay against human periodontal ligament cells. MTT Assay is a colorimetric analysis for testing the cytotoxicity of drugs in-vitro. It was observed that the cytotoxicity of the nanoparticle incorporated sealer was concentration dependent with the maximum cytotoxicity at a concentration of $10 \%$ of silver nanoparticles within the original sealer. It can be concluded that the nanoparticle incorporated sealer has more cytotoxicity when compared to the original composition and this is directly proportional to the concentration of the nanoparticles. More studies need to be done to analyse the clinical use of this nanoparticle incorporated sealer as evaluation of cytotoxicity levels alone does not qualify for a material to be used as an endodontic sealer.
\end{abstract}

KEY WORDS: ANTIBACTERIAL; CYTOTOXICITY; MTA; NANOPARTICLES; SEALER; SILVER.

\section{INTRODUCTION}

The success or failure of a root canal therapy depends on the complete elimination and disinfection of the root canal system. It has been proven from time to time that inability to remove the microbial biofilms has caused root canal therapies to fail (Ramachandran Nair, 1987; Lin, Skribner and Gaengler, 1992). The role of cleaning and disinfection using irrigants and medicaments cannot

\section{ARTICLE INFORMATION}

*Corresponding Author: iffatnasim@saveetha.com Received 13th June 2020 Accepted after revision 7th August 2020 Print ISSN: 0974-6455 Online ISSN: 2321-4007 CODEN: BBRCBA

Thomson Reuters ISI Web of Science Clarivate Analytics USA and Crossref Indexed Journal

\section{Clarivate}

NAAS Journal Score 2020 (4.31) SJIF: 2020 (7.728)

A Society of Science and Nature Publication,

Bhopal India 2020. All rights reserved.

Online Contents Available at: http//www.bbrc.in/

Doi: http://dx.doi.org/10.21786/bbrc/13.7/42 be overlooked. However, a three dimensional seal of the canal system that includes the root canal, its accessory canals and abnormal anatomy, if any is extremely important and forms a goal of the root canal therapy. Root canal sealers in conjunction with solid core filling materials aid in the sealing of the canal system three dimensionally (Kumaravadivel and Pradeep, 2016). Sealers help overcome the limitations of Gutta percha by filling minute microscopic space between the dentinal wall and gutta percha.

Sundqvist and Figdor (Orstavik, 2020) described three major functions of the root canal sealer as to seal canal systems against bacterial ingrowth from oral cavity, entombment of leftover viable microorganisms and complete obturation of the canal system at a submicroscopic level to prevent stagnant fluid from

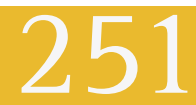


accumulation and serving as bacterial nutrition. Root canal sealers that possess superior sealing ability and antimicrobial activity would hence be beneficial in clinical aspects (Branstetter and von Fraunhofer, 1982) as they can not only prevent bacteria from re-entering and re-infecting the canal system but also inactivate the remaining viable bacteria of the canal system postobturation .

The ideal properties of sealers include establishment of hermetic seal, minimal cytotoxicity to periodontal ligament cells, tackiness when mixed to provide adhesion, radiopacity to be seen on a radiograph, lack of shrinkage and staining of tooth structure (ØRstavik, 2005). Traditional root canal sealers belong to the categories of zinc oxide eugenol (ZOE), epoxy resin (ER) and calcium hydroxide $(\mathrm{CH})$. This categorization is based on the basic composition of the sealers (Shin, Lee and Lee, 2018). Calcium silicate based cement consisting of added metal oxides lead to the development of Mineral Trioxide Aggregate (MTA) that has bioactive properties (Torabinejad and Chivian, 1999). Apart from being extremely biocompatible, it is seen to stimulate tissue repair and induce mineralisation (Camilleri et al., 2005; Parirokh and Torabinejad, 2010). These reasons make MTA a suitable material to be used as a root canal sealer as it fulfils most of the criteria for a material to be called an ideal root canal sealer.

Silver has gained a fame of being an antimicrobial agent and is being incorporated to check for its antimicrobial efficiency against various species of microorganisms important as per the dental perspective (Noronha et al., 2017). We have numerous highly cited publications on well designed clinical trials and lab studies (Govindaraju, Neelakantan and Gutmann, 2017; Azeem and Sureshbabu, 2018; Jenarthanan and Subbarao, 2018; Manohar and Sharma, 2018; Nandakumar and Nasim, 2018; Teja, Ramesh and Priya, 2018; Janani and Sandhya, 2019; Khandelwal and Palanivelu, 2019; Malli Sureshbabu et al., 2019; Poorni, Srinivasan and Nivedhitha, 2019; Rajakeerthi and Ms, 2019; Rajendran et al., 2019; Ramarao and Sathyanarayanan, 2019; Siddique and Nivedhitha, 2019; Siddique et al., 2019; Siddique, Nivedhitha and Jacob, 2019). This has provided the right platform for us to pursue the current study. Our aim was to evaluate the cytotoxicity of a MTA based sealer; MTA Fillapex, developed by Angelus (Londrina/Parana/ Brazil) against the human periodontal cell lines by MTT Colorimetric Assay in vitro.

\section{MATERIAL AND METHODS}

Silver nanoparticles (10nm), MTT(1-(4,5-Dimethylthiazol2-yl)-3,5-diphenylformazan) and DMSO purchased from Sigma Aldrich was used in this study. Silver nanoparticles $10 \mathrm{~nm}$ : AgNP $20 \mu \mathrm{g} / \mathrm{mL}$ solution (nanoparticles, $10 \mathrm{~nm}$ particle size), $0.02 \mathrm{mg} / \mathrm{mL}$ in aqueous buffer, contains sodium citrate as stabilizer. The endodontic sealer MTAFillapex, developed by Angelus (Londrina/Parana/ Brazil) and launched commercially in 2010 was mixed with $0.5 \%, 1.0 \%, 2.5 \%, 5 \%$, and $10 \%$ of silver nanoparticles.
Samples were prepared by mixing the silver nanoparticles percentages (by weight), proportionally incorporated into the base paste of the endodontic sealer and weighed. The $\mathrm{pH}$ value of the product was measured as 7.4. The concentration of the stock solution was $0.2 \mathrm{mM}$. The solution was stored at $4^{\circ} \mathrm{C}$. Serial dilutions from the $(100 \%)$ were made to obtain dilutions of $0.5 \%, 1.0 \%$, 2.5\%, 5\%, and 10\% in supplemented DMEM medium.

Human periodontal ligament cell lines were purchased from NCCS Pune, India.The PDL Cells were cultured in a humidified atmosphere at $37^{\circ} \mathrm{C}$ in the cell growth DMEM medium with 10\% fetal bovine serum, L-glutamine, $1 \%$ penicillin $(100 \mathrm{U} / \mathrm{ml})$, and streptomycin $(100 \mu \mathrm{g} / \mathrm{ml})$ at $37^{\circ} \mathrm{C}$ in a humidified CO2 (5\%) chamber and 95\% air. The cells were detached using 0.25\% EDTA Trypsin. Neutralization of the Trypsin was achieved using DMEM containing 10\% FBS and PSGF, and cells were mechanically separated using a pipette. There were 96well plastic culture plates filled with $200 \mu$ l of medium containing in each well. The plates were then incubated at $37^{\circ} \mathrm{C}$ in a humidified atmosphere containing 5\% CO2 and $95 \%$ air for $24 \mathrm{~h}$ to permit attachment of the cells to the plates.

Testing groups: The testing groups include negative control- only the medium without any test compound; sealer control - only the sealer without nanoparticles; sealer+silver nanoparticles - $(0.5,1.0,2.5,5,10 \%)$ of silver nanoparticles mixed with the sealer. The testing groups include negative control- only the medium without any test compound; sealer control - only the MTA without nanoparticles; MTA + silver nanoparticles - $(0.5,1.0,2.5,5,10 \%)$ of silver nanoparticles mixed with the sealer.

Cell viability assay: The PDL cells were seeded at the density of $(1 \times 103$ cells $/ \mathrm{ml})$ were plated on into well plates and the cells were permitted to adhere for 24 hours, and the growth medium (MEM) removed using micropipette and the monolayer of cells washed twice with MEM without FBS to remove dead cells and excess FBS. Then treated with $100 \mu \mathrm{l}$ of different concentrations of MTA + AgNps and MTA alone in respective wells for $24 \mathrm{~h}$. Cell culture medium (DMEM) was used as a negative control for assessment of cell viability. $200 \mu \mathrm{l}$ of MTT (5 $\mathrm{mg} / \mathrm{ml}$ in PBS) were added to each well, and the cells incubated for a further 6-7 hrs in 5\% CO2 incubator. After removal of the medium, $1 \mathrm{ml}$ of DMSO was added to each well. The effect of the MTA + AgNps (0.5, 1.0, 2.5, $5,10 \%$ ) and sealer control on cell growth inhibition was assessed as percent cell viability, where vehicle-treated cells were taken as 100\% viable.

The supernatant was removed and $50 \mu \mathrm{l}$ of propanol was added and the plates were gently shaken to solubilize the formed formazan. The MTT enters the cells and passes into the mitochondria where it is reduced to an insoluble, coloured (dark purple) formazan product. Since reduction of MTT can only occur in metabolically active cells the level of activity is a measure of the viability of the cells. The plates were placed on a shaker for 15 
min and the absorbance was read on an enzyme-linked immunosorbent assay (ELISA) reader at $570 \mathrm{~nm}$. From the values obtained, the percentage cytotoxicity (IC50 value) was calculated. Each experiment was carried out in triplicate and the half maximal inhibitory concentration (IC50) of the test samples as the percentage survival of the cells was calculated according to the formula provided below:

Percentage of viable cell concentration was calculated thus:

Viability $(\%)=($ Mean test $0 D /$ Control OD $) \times 100$

Statistical analysis: Results were expressed as mean \pm Standard error of Mean (SEM). Statistical significance was determined by one-way analysis of variance (ANOVA) and post hoc least-significant difference test. $P$ values less than 0.05 were considered significant.

Table 1: Table showing \% of cell viability after MTT Assay was performed. Values are expressed as Mean \pm Standard error of Mean (SEM). $(n=3)$; MTA + AgNPS treated PDL cells showed statistically significant difference ${ }^{*} \mathrm{P}<0.05$; ${ }^{* *} \mathrm{P}<0.01 ;{ }^{* * *} \mathrm{P}<0.001$ as compared with Negative control. MTA alone treated PDL cells showed statistically significant difference \# $\mathrm{P}<0.001$ as compared with Negative control. The IC50 of the MTA + AgNPS is $4.52 \%$.

\begin{tabular}{|c|l|c|c|c|}
\hline $\begin{array}{c}\text { S. } \\
\text { No }\end{array}$ & Treatment & $\begin{array}{c}\text { Conc } \\
(\%)\end{array}$ & $\begin{array}{c}\text { Absorbance } \\
570 \mathrm{~nm}\end{array}$ & $\begin{array}{c}\% \text { of cell } \\
\text { viability }\end{array}$ \\
\hline 1. & $\begin{array}{c}\text { PDL untreated } \\
\text { cells }\end{array}$ & & $0.427 \pm 0.11$ & $100 \pm 7.6$ \\
\hline 2. & MTA Control & 1.0 & $0.376 \pm 0.25$ & $88.3 \pm 2.7^{*}$ \\
\hline 3. & MTA+AgNPs & 0.5 & $0.315 \pm 0.14$ & $73.7 \pm 3.8^{*}$ \\
\hline 4. & MTA+AgNPs & 1.0 & $0.295 \pm 0.19$ & $69.0 \pm 1.9^{* *}$ \\
\hline 5. & MTA+AgNPs & 2.5 & $0.236 \pm 0.11$ & $55.2 \pm 2.4^{* * *}$ \\
\hline 6. & MTA+AgNPs & 5.0 & $0.195 \pm 0.23$ & $45.6 \pm 1.5^{* * *}$ \\
\hline 7. & MTA+AgNPs & 10.0 & $0.107 \pm 0.11$ & $25.0 \pm 1.2 \#$ \\
\hline
\end{tabular}

\section{RESULTS AND DISCUSSION}

In the current study cytotoxicity analysis was done using MTT Assay which is a colorimetric test. The MTT (3-[4,5dimethylthiazol-2-yl]-2,5 diphenyl tetrazolium bromide) assay is based upon the conversion of MTT to formazan crystals that determine the mitochondrial activity of living cells (van Meerloo, Kaspers and Cloos, 2011). The formazan crystals presence in the cells can be evaluated by spectrophotometer. For most cell populations' total mitochondrial activity is related to the number of viable cells . MTT assay, hence broadly is used to measure the in vitro cytotoxic effects of drugs and dental materials on cell lines or primary cells lines. As seen in the results (Table 1 and Figure 1), the incorporation of nanosilver particles increases the cytotoxicity of the PDL cells and decreases the cell viability proportionally as the increase in the concentration of the silver nanoparticles is seen. Minimum cytotoxicity is seen in the original product while maximum is seen when $10 \%$ of silver nanoparticles are added. The mechanism of cytotoxicity of the silver nanoparticles in vitro to PDL cells reportedly is due to the interaction of the nanoparticles with mitochondria and other cell organelles after they have phagocytized into the cells. This results in cells' apoptosis or necrosis. (Wei et al., 2010).

Figure 1: Bar graph depicting the \% of viable cells $\mathrm{X}$-axis denotes the nature of the test product used and Y-axis denotes the \% of periodontal cells viable after the performance of MTT Assay. It can be inferred that maximum \% of the periodontal cell viability was seen when MTA with no silver nanoparticles were added. The $\%$ of cell viability is concentration of silver nanoparticles incorporation dependent.

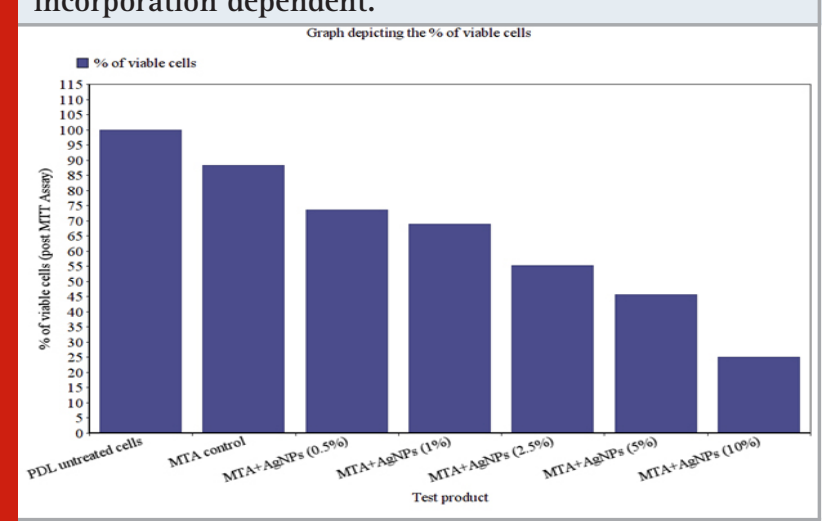

Since ancient times, the silver ion has been known to be effective against a broad range of microorganisms. Silver ions are used to control bacterial growth in a variety of medical applications, including dental work, catheters, and the healing of burn wounds. The mechanism of the antimicrobial action of silver ions is closely related to their interaction with thiol (sulfhydryl) groups and it has a deadly effect on bacterial enzymes, bacterial growth and cell division and result in damage of bacterial cell wall and contents (Jung et al., 2008). The addition of nanoparticles to the endodontic sealers help in an interaction at the molecular level. Silver particles are extremely efficient when delivered in particles of nano ranges. The nano range comprises particles with a size of 1 to $100 \mathrm{~nm}$ range. The silver nanoparticles are stored in a liquid medium to prevent agglomeration and entrapment of the particles within the matrix.

It has been implied that the particle shape, size, distribution and agglomeration are important characteristics of nanoparticles (Lara et al., 2011). These factors determine the distribution of the particles in vivo, their biological fate, toxic effects, and targeting ability. Silver nanoparticles are non-toxic at low concentrations and have a broad spectrum of antimicrobial activity that includes many gram positive, gram negative and antibiotic drug resistant species like MRSA (Morones et al., 2005). The antimicrobial mechanism of action of silver nanoparticles can be attributed to its greater ability of binding to the negatively charged part of the bacterial cell wall causing the rupture of the cell membrane and subsequent leak in the cytoplasmic 
contents of the microorganisms. Furthermore, the nanoparticles infiltrate within the cytoplasm and interact with the nuclear content causing bacterial cell death (Ibrahim et al., 2017) . This was the idea behind inclusion of silver nanoparticles in a MTA based sealer.

MTA Fillapex, developed by Angelus (Londrina/Parana/ Brazil) and launched commercially in 2010, is seen to comprise natural resin, salicylate resin, diluting resin, bismuth trioxide, nanoparticulated silica, MTA and pigments (Bin et al., 2012). There have been claims that MTA Fillapex has a good antimicrobial efficiency (Rahman et al., 2017; Faria-Júnior et al., 2013; Kuga et al., 2013; Ustun et al., 2013; Hasheminia et al., 2017). The product claims to provide high alkalinity that favours hard tissue remineralisation and offers good antimicrobial activity (Kuga et al., 2011; Borges et al., 2014). Physical properties of MTA Fillapex when compared to commonly used epoxy resin based sealers are acceptable and MTA Fillapex has shown lowest values of flow, shorter working and setting times, lesser solubility and water absorption and good radiopacity, making it a clinically acceptable and desirable endodontic sealer (Vitti et al., 2013).

In the current scenario, epoxy resin based sealers are seen to possess very good physical properties, excellent apical sealing ability and biocompatibility (Singh et al., 2015). AH 26 releases formaldehyde hence its use has been questionable and this resin based sealer is being replaced with $\mathrm{AH}$ Plus which is a more biocompatible option (Spångberg, Barbosa and Lavigne, 1993; Huang et al., 2002). Zinc oxide eugenol based sealers have released potentially cytotoxic concentrations of eugenol that affect the viability of periodontal cells (Jung et al., 2018). Calcium hydroxide based sealers promote calcification but dissolution over a period of time remains a challenge (Khashaba, Chutkan and Borke, 2009).

Calcium silicate based sealer MTA Fillapex, developed by Angelus (Londrina/Parana/ Brazil), is reported to have a similar or greater cytotoxicity when compared to conventionally used sealers as reported by few authors when cytotoxicity studies on various cell lines like human periodontal cell lines, human gingival fibroblasts and primary human osteoblasts were performed (Bin et al., 2012; Scelza et al., 2012; Silva et al., 2013; Zhou et al., 2015; Collado-González et al., 2017; Poggio et al., 2017; Saygili et al., 2017) . A time- and dose-dependent response has been reported when MTA Fillapex was tested in-vitro for cytotoxicity analysis (Yoshino et al., 2013; Jafari et al., 2017). In our study, hence it is evident that with the addition of silver nanoparticles, though there may be an increase in the antibacterial activity of the sealer, there definitely is an increase in the cytotoxicity of the dental material which is dose dependent in nature. The decision of using this nanoparticle incorporated root canal sealer needs to be made after balancing all the desired properties and requirements. More tests need to be carried out for the cytotoxic and genotoxic analysis of this nanoparticle incorporated sealer. However, an endodontic sealer that is ideal for use appears as a myth even today.

\section{CONCLUSION}

Nanoparticulate dental materials are the future of dentistry. The in-vitro study gives us a perspective of nanosilver particle modified MTA based sealers to be cytotoxic to the human periodontal cells in a concentration dependent fashion. However, more clinical oriented studies need to be done to check for other aspects like toxicity, discoloration or microleakage in the canal of this nanosilver modified sealer.

Conflict of Interest: The authors deny any conflict of interests related to this study.

\section{REFERENCES}

Azeem, R. A. and Sureshbabu, N. M. (2018) 'Clinical performance of direct versus indirect composite restorations in posterior teeth: A systematic review', Journal of conservative dentistry: JCD, 21(1), pp. 2-9. Bin, C. V. et al. (2012) 'Cytotoxicity and genotoxicity of root canal sealers based on mineral trioxide aggregate', Journal of endodontia, 38(4), pp. 495-500.

Borges, Á. H. et al. (2014) 'Physicochemical properties and surfaces morphologies evaluation of MTA FillApex and AH plus', TheScientificWorldJournal. hindawi.com, 2014, p. 589732.

Branstetter, J. and von Fraunhofer, J. A. (1982) 'The physical properties and sealing action of endodontic sealer cements: a review of the literature', Journal of endodontia, 8(7), pp. 312-316.

Camilleri, J. et al. (2005) 'The constitution of mineral trioxide aggregate', Dental materials: official publication of the Academy of Dental Materials. Elsevier, 21(4), pp. 297-303.

Collado-González, M. et al. (2017) 'Cytotoxicity of GuttaFlow Bioseal, GuttaFlow2, MTA Fillapex, and AH Plus on Human Periodontal Ligament Stem Cells', Journal of endodontia, 43(5), pp. 816-822.

Faria-Júnior, N. B. et al. (2013) 'Antibiofilm activity, pH and solubility of endodontic sealers', International endodontic journal. Wiley Online Library, 46(8), pp. 755-762.

Govindaraju, L., Neelakantan, P. and Gutmann, J. L. (2017) 'Effect of root canal irrigating solutions on the compressive strength of tricalcium silicate cements', Clinical oral investigations, 21(2), pp. 567-571.

Hasheminia, M. et al. (2017) 'In vitro evaluation of the antibacterial activity of five sealers used in root canal therapy', Dental research journal, 14(1), pp. 62-67.

Huang, T.-H. et al. (2002) 'The biocompatibility evaluation of epoxy resin-based root canal sealers in vitro', Biomaterials. Elsevier, 23(1), pp. 77-83.

Ibrahim, A. I. 0. et al. (2017) 'Use of antibacterial nanoparticles in Endodontics', South African dental journal. Suid Afrikaanse tandarts tydskrif. The South African Dental Association (SADA), 72(3), pp. 105112.

Jafari, F. et al. (2017) 'In vitro Cytotoxicity Comparison 
of MTA Fillapex, AH-26 and Apatite Root Canal Sealer at Different Setting Times', Iranian endodontic journal, 12(2), pp. 162-167.

Janani, K. and Sandhya, R. (2019) 'A survey on skills for cone beam computed tomography interpretation among endodontists for endodontic treatment procedure', Indian journal of dental research: official publication of Indian Society for Dental Research, 30(6), pp. 834-838.

Jenarthanan, S. and Subbarao, C. (2018) 'Comparative evaluation of the efficacy of diclofenac sodium administered using different delivery routes in the management of endodontic pain: A randomized controlled clinical trial', Journal of conservative dentistry: JCD, 21(3), pp. 297-301.

Jung, S. et al. (2018) 'Cytotoxic effects of four different root canal sealers on human osteoblasts', PloS one. ncbi. nlm.nih.gov, 13(3), p. e0194467.

Jung, W. K. et al. (2008) 'Antibacterial activity and mechanism of action of the silver ion in Staphylococcus aureus and Escherichia coli', Applied and environmental microbiology, 74(7), pp. 2171-2178.

Khandelwal, A. and Palanivelu, A. (2019) 'Correlation Between Dental Caries And Salivary Albumin In Adult Population In Chennai: An In Vivo Study', Brazilian Dental Science, 22(2), pp. 228-233.

Khashaba, R. M., Chutkan, N. B. and Borke, J. L. (2009) 'Comparative study of biocompatibility of newly developed calcium phosphate-based root canal sealers on fibroblasts derived from primary human gingiva and a mouse L929 cell line', International endodontic journal. Wiley Online Library, 42(8), pp. 711-718.

Kuga, M. C. et al. (2011) 'Hydrogen ion and calcium releasing of MTA Fillapex ${ }^{\circledR}$ and MTAbased formulations', RSBO Revista Sul-Brasileira de Odontologia. Universidade da Região de Joinville, 8(3), pp. 271-276.

Kuga, M. C. et al. (2013) 'Evaluation of the pH, calcium release and antibacterial activity of MTA Fillapex', Revista de odontologia da UNESP / Universidade Estadual Paulista . Revista de Odontologia da UNESP/ Universidade Estadual Paulista Júlio de Mesquita Filho, 42(5), pp. 330-335.

Kumaravadivel, M. S. and Pradeep, D. S. (2016) 'RECENT ADVANCEMENTS OF ENDODONTIC SEALERS-A REVIEW'. Available at: https://www.semanticscholar. org/paper/712343154ffa2f5e6d0af54f29b2bcc920a772 bc (Accessed: 1 June 2020).

Lara, H. H. et al. (2011) 'Silver nanoparticles are broadspectrum bactericidal and virucidal compounds', Journal of nanobiotechnology. Springer, 9, p. 30.

Lin, L. M., Skribner, J. E. and Gaengler, P. (1992) 'Factors associated with endodontic treatment failures', Journal of endodontia. Elsevier, 18(12), pp. 625-627.

Malli Sureshbabu, N. et al. (2019) 'Concentrated Growth Factors as an Ingenious Biomaterial in Regeneration of Bony Defects after Periapical Surgery: A Report of Two
Cases', Case reports in dentistry, 2019, p. 7046203. Manohar, M. P. and Sharma, S. (2018) 'A survey of the knowledge, attitude, and awareness about the principal choice of intracanal medicaments among the general dental practitioners and nonendodontic specialists', Indian journal of dental research: official publication of Indian Society for Dental Research, 29(6), pp. 716-720.

van Meerloo, J., Kaspers, G. J. L. and Cloos, J. (2011) 'Cell Sensitivity Assays: The MTT Assay', in Cree, I. A. (ed.) Cancer Cell Culture: Methods and Protocols. Totowa, NJ: Humana Press, pp. 237-245.

Morones, J. R. et al. (2005) 'The bactericidal effect of silver nanoparticles', Nanotechnology. iopscience.iop. org, 16(10), pp. 2346-2353.

Nandakumar, M. and Nasim, I. (2018) 'Comparative evaluation of grape seed and cranberry extracts in preventing enamel erosion: An optical emission spectrometric analysis', Journal of conservative dentistry: JCD, 21(5), pp. 516-520.

Noronha, V. T. et al. (2017) 'Silver nanoparticles in dentistry', Dental materials: official publication of the Academy of Dental Materials. Elsevier, 33(10), pp. 1110-1126.

Orstavik, D. (2020) Essential Endodontology: Prevention and Treatment of Apical Periodontitis. John Wiley \& Sons.

ØRstavik, D. A. G. (2005) 'Materials used for root canal obturation: technical, biological and clinical testing', Endodontic topics. Blackwell Publishing Ltd Oxford, UK, 12(1), pp. 25-38.

Parirokh, M. and Torabinejad, M. (2010) 'Mineral Trioxide Aggregate: A Comprehensive Literature Review-Part III: Clinical Applications, Drawbacks, and Mechanism of Action', Journal of endodontics. Elsevier, 36(3), pp. 400-413.

Poggio, C. et al. (2017) 'Comparative cytotoxicity evaluation of eight root canal sealers', Journal of clinical and experimental dentistry, 9(4), pp. e574-e578.

Poorni, S., Srinivasan, M. R. and Nivedhitha, M. S. (2019) 'Probiotic strains in caries prevention: A systematic review', Journal of conservative dentistry: JCD, 22(2), pp. 123-128.

Rahman, H. et al. (2017) 'Antimicrobial Activity of MTA Fillapex, Real Seal SE, Acroseal and Zinc oxide Eugenol Sealers against Enterococcus Faecalis and Candida Albicans'. doi: 10.9790/0853-1601066.

Rajakeerthi, R. and Ms, N. (2019) 'Natural Product as the Storage medium for an avulsed tooth - A Systematic Review', Cumhuriyet Dental Journal, 22(2), pp. 249256.

Rajendran, R. et al. (2019) 'Comparative Evaluation of Remineralizing Potential of a Paste Containing Bioactive Glass and a Topical Cream Containing Casein Phosphopeptide-Amorphous Calcium Phosphate: An in Vitro Study', Pesquisa brasileira em odontopediatria e clinica integrada, 19(1), pp. 1-10. 
Ramachandran Nair, P. N. (1987) 'Light and electron microscopic studies of root canal flora and periapical lesions', Journal of endodontia, 13(1), pp. 29-39.

Ramarao, S. and Sathyanarayanan, U. (2019) 'CRA Grid - A preliminary development and calibration of a paper-based objectivization of caries risk assessment in undergraduate dental education', Journal of conservative dentistry: JCD, 22(2), pp. 185-190.

Saygili, G. et al. (2017) 'In Vitro Cytotoxicity of GuttaFlow Bioseal, GuttaFlow 2, AH-Plus and MTA Fillapex', Iranian endodontic journal, 12(3), pp. 354359.

Scelza, M. Z. et al. (2012) 'A multiparametric assay to compare the cytotoxicity of endodontic sealers with primary human osteoblasts', International endodontic journal. Wiley Online Library, 45(1), pp. 12-18.

Shin, J.-H., Lee, D.-Y. and Lee, S.-H. (2018) 'Comparison of antimicrobial activity of traditional and new developed root sealers against pathogens related root canal', Journal of dental sciences. Elsevier, 13(1), pp. 54-59.

Siddique, R. et al. (2019) 'Qualitative and quantitative analysis of precipitate formation following interaction of chlorhexidine with sodium hypochlorite, neem, and tulsi', Journal of conservative dentistry: JCD, 22(1), pp. 40-47.

Siddique, R. and Nivedhitha, M. S. (2019) 'Effectiveness of rotary and reciprocating systems on microbial reduction: A systematic review', Journal of conservative dentistry: JCD, 22(2), pp. 114-122.

Siddique, R., Nivedhitha, M. S. and Jacob, B. (2019) 'Quantitative analysis for detection of toxic elements in various irrigants, their combination (precipitate), and para-chloroaniline: An inductively coupled plasma mass spectrometry study', Journal of conservative dentistry: JCD, 22(4), pp. 344-350.
Silva, E. J. N. L. et al. (2013) 'Evaluation of cytotoxicity and physicochemical properties of calcium silicatebased endodontic sealer MTA Fillapex', Journal of endodontia, 39(2), pp. 274-277.

Singh, H. et al. (2015) 'Endodontic sealers: Current concepts and comparative analysis', Dent Open J. pdfs. semanticscholar.org, 2(1), pp. 32-37.

Spångberg, L. S. W., Barbosa, S. V. and Lavigne, G. D. (1993) 'AH26 releases formaldehyde', Journal of endodontics. Elsevier, 19(12), pp. 596-598.

Teja, K. V., Ramesh, S. and Priya, V. (2018) 'Regulation of matrix metalloproteinase-3 gene expression in inflammation: A molecular study', Journal of conservative dentistry: JCD, 21(6), pp. 592-596.

Torabinejad, M. and Chivian, N. (1999) 'Clinical applications of mineral trioxide aggregate', Journal of endodontia. Elsevier, 25(3), pp. 197-205.

Ustun, Y. et al. (2013) 'In vitro antimicrobial efficiency of different root canal sealers against Enterecoccus faecalis', European Journal of General Dentistry. Medknow Publications and Media Pvt. Ltd., 2(2), p. 134.

Vitti, R. P. et al. (2013) 'Physical properties of MTA Fillapex sealer', Journal of endodontia, 39(7), pp. 915-918.

Wei, L. et al. (2010) 'Investigation of the cytotoxicity mechanism of silver nanoparticles in vitro', Biomedical materials , 5(4), p. 044103.

Yoshino, P. et al. (2013) 'In Vitro Cytotoxicity of White MTA, MTA Fillapex ${ }^{\circledR}$ and Portland Cement on Human Periodontal Ligament Fibroblasts', Brazilian dental journal. Fundação Odontológica de Ribeirão Preto, 24(2), pp. 111-116.

Zhou, H.-M. et al. (2015) 'In Vitro Cytotoxicity of Calcium Silicate-containing Endodontic Sealers', Journal of endodontics. Elsevier, 41(1), pp. 56-61. 